\title{
Life After Tenure: Stay Fresh Via A Sabbatical
}

\author{
Glenn R. Blackwell, P.E. \\ Purdue University \\ West Lafayette, IN 47907
}

\begin{abstract}
The sabbatical leave is a tool which may be used by faculty members to refresh and renew themselves after at least seven years of employment. The author has taken two sabbatical leaves, each with a significantly different set of goals. This paper encourages relatively new educators to consider the sabbatical leave as a worthwhile part of their academic career.
\end{abstract}

\section{Introduction}

After the tenure-and-promotion process has resulted in a tenured position, hopefully at a higher academic rank, there may be a tendency to think "I've made it, now I can take a break". Well, in this author's opinion, in the classroom is the wrong place to take a "break". That's why you got into the world of academia, to work hard and do well by and for your students! But the need for a break is real, and that is the purpose of a sabbatical leave.

The need for a sabbatical leave has been documented in the literature (1). University faculty typically work long hours during the academic year and in many cases during the breaks and the summer term. In addition most university faculty recognize that their ability to teach and/or do research in their chosen field is enhanced by the opportunity to involve themselves in work which is not as directly related to their academic world $(2,3)$. The ability to be away from the campus setting can allow different views and interpretations of the topics normally pursued on campus. Other reasons for a sabbatical leave include allowing the faculty member to become part of the industrial environment, allowing better correlation between topics which are taught in the classroom and the knowledge actually used by graduates in industry $(4,5)$.

\section{Criteria for a sabbatical}

Typically the faculty member requesting a sabbatical leave must have been employed as a faculty member for a minimum of seven years, or have worked at least seven years since a prior sabbatical leave. S/he will make a proposal to his/her department head, although there is no requirement nor need to make the proposal immediately during the seventh year. Unlike many

\footnotetext{
"Proceedings of the 2001 American Society for Engineering Education Annual Conference and Exposition. Copyright 2001, American Society for Engineering Education"
} 
situations, a sabbatical leave is not "use it or lose it". It can be requested literally any time after the seventh year with no prejudice on timing. The department head may or may not be able to make a decision at his/her level. At the author's home institution, the department head, the Dean of the School, and the Sr. VP for Academic Affairs must all approve sabbatical leaves. This paper will describe in some detail the criteria typically involved in sabbatical proposals by faculty, and considerations of those proposals by administrators.

The rationale for and definition of a sabbatical are both simple and complex. They are simple because everyone understands that a sabbatical is a periodic paid leave that is available to educational faculty to allow them to pursue (typically) off-campus interests. It is complex because every institution handles them differently and even within an institution different schools and departments may define a sabbatical in different ways.

One dictionary(6) says that a sabbatical year is:

a leave of absence with pay, usually granted every seven years, as to a college professor, for travel, research, or rest.... Also called "sabbatical leave".

Faculty expectations are that a sabbatical leave may allow them to study and/or work in areas related to the areas they currently teach and/or do research in, may allow them to study or work in new areas, and may allow them to rest and recuperate (R\&R) from the rigors of university life.

A sabbatical leave may allow a history faculty member to travel to Italy for a year and investigate the history of aspects of the Roman empire. A sabbatical leave for an engineering or engineering technology faculty member may involve work in an industrial setting to gain knowledge of the applications of theory normally taught by the faculty member. Since it is expected that the readers of this article will be in technical disciplines, the remainder of this article will focus on sabbatical leaves related to faculty in those disciplines. It must also be noted that each institution handles sabbatical leave requests in its own fashion. Therefore readers must not take procedural comments in this article as correct for their own institutions, but must find out the rules and regulations governing their own situation, some of which may not be in writing.

At the author's institution, a sabbatical must be originated with a request/proposal to the initiator's home department head. If approved there, it must be approved by the Dean of the school and then by the Executive Vice President for Academic Affairs (EVPAA). It would be unusual for a request to be denied by the EVPAA if approved by the Head of the department and the Dean of the school. During the term of the sabbatical leave at this institution, the faculty member is paid $1 / 2$ his/her academic-year salary and all benefits are continued during the term of the sabbatical. A faculty member may additionally be paid by others for his/her sabbatical work, but may not accrue total compensation greater than the compensation that faculty member would normally accrue during full-time service at the university. This total compensation does not include any paid relocation or living expenses which may be paid by a third party. The compensation provision prevents a sabbatical leave from being requested for monetary reasons, which is not their intent. If the reader wants to make more money s/he probably needs to find a position in industry rather than one in academia.

"Proceedings of the 2001 American Society for Engineering Education Annual Conference and Exposition. Copyright 2001, American Society for Engineering Education” 


\section{Examples of two sabbatical leaves}

The author teaches in the Electrical Engineering Technology department of the School of Technology at Purdue University. Within this School, a sabbatical proposal is most likely to be approved by a department head and by the Dean if the proposal involves industrial experience on the part of the faculty member and if the work will generally take place away from the campus location. Sabbatical leaves involving other criteria have been approved but most commonly these criteria are followed. The requirement for an industrial position recognizes the Schools' mission of preparing students for successful careers in industry. The "away" requirement is to try to maximize the probability the faculty member will not be tempted to partake in "normal" on-campus activities such as faculty meetings!

The author's first sabbatical leave proposal, for the 1992-1993 academic year, was to spend a year working as a Senior Project Engineer at Delco Electronics Corp. The involvement by the Electronics Manufacturing Development group at Delco was easy to solicit and accomplish since Delco had the opportunity to hire an experienced engineer for less than the total cost of an entrylevel engineer with no experience. It was agreed that the author would be involved in work at Delco on a standard 40-hour workweek schedule. Delco felt this schedule would maximize the author's understanding of both industrial technical topics as well as industrial protocols that graduates would be expected to be part of. This sabbatical involved the author in a variety of projects that were related to topics the author taught at Purdue, including electronic manufacturing, automated electronic testing, and automated optical inspections. It also involved $1-1 / 2$ hours of commuting time each day, which combined with a 40 -hour work-week meant that the R\&R aspect of the sabbatical was minimal. At the end of the sabbatical term most of the sabbatical goals were accomplished, and the author returned to campus duty with a larger body of knowledge in electronics manufacturing and testing.

The second sabbatical, during the 2000 calendar year, involved no 40 hour week schedule but rather involved a combination of tasks which were related to the author's university assignments:

- work as a consultant on a project with an industrial partner, but with an independent schedule

- develop applications of a software package which could be implemented in one of the undergraduate courses taught in the author's department

- write in the areas of interest to the author

This sabbatical also took place at some distance from campus, which meant a temporary move of the household. The majority of sabbatical leaves at Purdue with which the author is familiar include a temporary move from the campus locale.

The R\&R component of this sabbatical was considerably higher than in the first sabbatical while still providing positive experiences related to the author's academic assignments. This sabbatical did require a much higher level of self-discipline, since there was no daily commute to enforce the work times. Obviously this translated into some days with a number of work hours, and other days with no work hours. At the end of the sabbatical term most, although not all, of the sabbatical goals were accomplished, but the author believes the result was beneficial to both himself and his department.

\footnotetext{
"Proceedings of the 2001 American Society for Engineering Education Annual Conference and Exposition. Copyright 2001, American Society for Engineering Education"
} 
Comparing the two sabbatical leaves:

Experiences related to the author's assigned areas

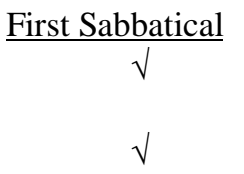

$\underline{\text { Second Sabbatical }}$

Experiences somewhat afield from assigned areas

Remuneration equal to full-time faculty status

Rest and Recuperation

The author feels that both sabbatical leaves were of great value to him and his department. The advantages and disadvantages of each can be used by the reader to consider how s/he may want to view a sabbatical leave. From those considerations the reader can begin to formulate a sabbatical proposal.

\section{Conclusion}

While a sabbatical leave is not "due" a seven-year faculty member, in the same sense that sick leave is "due" a sick faculty member, the author believes the sabbatical leave is a very valuable part of keeping each faculty member's work fresh and up-to-date. For this reason, once tenure is achieved, faculty in a given department should begin to think about how a sabbatical leave could be of value to individual faculty members, the students and the university. The author feels it is in the best interest of many academic departments to encourage eligible faculty members to develop sabbatical proposals.

For individual faculty, discussions between the faculty member and the department head should provide a good indication of how the department head views sabbatical leaves and from that a good sense of the type and content of a proposal that is most likely to be viewed positively. For each individual, a leave should be requested at an appropriate time and for appropriate reasons. Good luck.

\section{Bibliography}

1. Wyman, Max; “Tenure, Tenure Procedures, and Sabbatical Leaves”. Queen’s Quarterly, v. 80, \#1, Spring 1973, p12-21.

2, Coleman, G.; "Someone get the phone - I'm on sabbatical”. J. of Environmental Health, v.62, \#4, Nov. 1999, $\mathrm{p} 4+$.

3. Maki, WS, Maki, RH; “Learning without lectures: a case study”. Computer, v3, \#5, May 97, p107-111.

4. Schenck, JP; “Quality assurance and education-the sabbatical”. Quality Progress, v26, \#7, July 93, p69-71.

5. Mitchell, W; "Retraining the trainer: a view from both sides". Interface: the Computer Education Quarterly, v9, \#2, Summer 87, p5-7.

6. Morris, W, ed.; The American Heritage Dictionary of the English Language. Houghton Mifflin Co., Boston, 1979. "Proceedings of the 2001 American Society for Engineering Education Annual Conference and Exposition.
Copyright 2001, American Society for Engineering Education" 